University of Vermont

UVM ScholarWorks

Rubenstein School of Environment and Natural Rubenstein School of Environment and Natural Resources Faculty Publications

$11-1-2010$

\title{
A hitchhiker's guide to the Maritimes: Anthropogenic transport facilitates long-distance dispersal of an invasive marine crab to Newfoundland
}

\author{
A. M.H. Blakeslee \\ Smithsonian Environmental Research Center \\ C. H. McKenzie \\ Northwest Atlantic Fisheries Centre, Fisheries and Oceans Canada \\ J. A. Darling \\ United States Environmental Protection Agency \\ J. E. Byers \\ University of Georgia \\ J. M. Pringle \\ University of New Hampshire Durham
}

See next page for additional authors

Follow this and additional works at: https://scholarworks.uvm.edu/rsfac

Part of the Climate Commons

\section{Recommended Citation}

Blakeslee AM, McKenzie CH, Darling JA, Byers JE, Pringle JM, Roman J. A hitchhiker's guide to the Maritimes: anthropogenic transport facilitates long-distance dispersal of an invasive marine crab to Newfoundland. Diversity and Distributions. 2010 Nov;16(6):879-91.

This Article is brought to you for free and open access by the Rubenstein School of Environment and Natural Resources at UVM ScholarWorks. It has been accepted for inclusion in Rubenstein School of Environment and Natural Resources Faculty Publications by an authorized administrator of UVM ScholarWorks. For more information, please contact scholarworks@uvm.edu. 


\section{Authors}

A. M.H. Blakeslee, C. H. McKenzie, J. A. Darling, J. E. Byers, J. M. Pringle, and J. Roman 


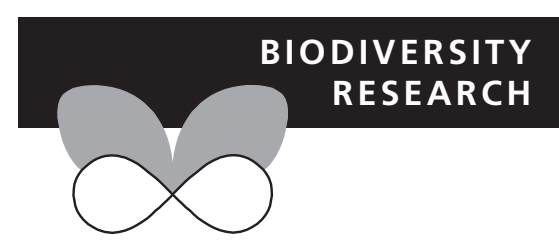

\title{
A hitchhiker's guide to the Maritimes: anthropogenic transport facilitates long-distance dispersal of an invasive marine crab to Newfoundland
}

\author{
A. M. H. Blakeslee ${ }^{1 \star}$, C. H. McKenzie ${ }^{2}$, J. A. Darling ${ }^{3}$, J. E. Byers ${ }^{4}$, \\ J. M. Pringle ${ }^{5}$ and J. Roman ${ }^{6}$
}

${ }^{1}$ Marine Invasions Laboratory, Smithsonian Environmental Research Center, Edgewater, MD 21037, USA, ${ }^{2}$ Northwest Atlantic Fisheries Centre, Fisheries and Oceans Canada, 80 White Hills, St. John's, NL A1C 5X1, Canada, ${ }^{3}$ Molecular Ecology Research Branch, National Exposure Research Laboratory, US Environmental Protection Agency, 26 Martin Luther King Drive, Cincinnati, OH 45268, USA, ${ }^{4}$ Odum School of Ecology, University of Georgia, 140 E. Green St., Athens, GA 30602, USA, ${ }^{5}$ Institute for the Study of Earth, Ocean and Space, University of New Hampshire, 39 College Road, Durham, NH 03824, USA, ${ }^{6}$ Gund Institute for Ecological Economics, University of Vermont, 617 Main Street, Burlington, VT 05443, USA

${ }^{*}$ Correspondence: A. M. H. Blakeslee, Marine Invasions Laboratory, Smithsonian Environmental Research Center, Edgewater, MD 21037, USA.

E-mail: blakesleea@si.edu

\begin{abstract}
Aim To determine timing, source and vector for the recent introduction of the European green crab, Carcinus maenas (Linnaeus, 1758), to Newfoundland using multiple lines of evidence.
\end{abstract}

Location Founding populations in Placentia Bay, Newfoundland, Canada and potential source populations in the north-west Atlantic (NWA) and Europe.

Methods We analysed mitochondrial and microsatellite genetic data from European and NWA populations sampled during 1999-2002 to determine probable source locations and vectors for the Placentia Bay introduction discovered in 2007. We also analysed Placentia Bay demographic data and shipping records to look for congruent patterns with genetic analyses.

Results Demographic data and surveys suggested that $C$. maenas populations are established and were in Placentia Bay for several years (c. 2002) prior to discovery. Genetic data corroboratively suggested central/western Scotian Shelf populations (e.g., Halifax) as the likely source area for the anthropogenic introduction. These Scotian Shelf populations were within an admixture zone made up of genotypes from both the earlier (early 1800s) and later (late 1900s) introductions of the crab to the NWA from Europe. Placentia Bay also exhibited this mixed ancestry. Probable introduction vectors included vessel traffic and shipping, especially vessels carrying ballast water.

Main conclusions Carcinus maenas overcame considerable natural barriers (i.e., coastal and ocean currents) via anthropogenic transport to become established and abundant in Newfoundland. Our study thus demonstrates how non-native populations can be important secondary sources of introduction especially when aided by human transport. Inference of source populations was possible owing to the existence of an admixture zone in central/western Nova Scotia made up of southern and northern genotypes corresponding with the crab's two historical introductions. Coastal vessel traffic was found to be a likely vector for the crab's spread to Newfoundland. Our study demonstrates that there is considerable risk for continued introduction or reintroduction of $C$. maenas throughout the NWA.

\section{Keywords}

Anthropogenic introduction, biological invasions, Carcinus maenas, microsatellite loci, mitochondrial DNA, Newfoundland, north-west Atlantic.

\section{INTRODUCTION}

Documenting the source of invasive species can be difficult, especially if an invader has numerous potential sources or is lacking a well-documented invasion history (Roman \& Darling, 2007). Even recent or highly conspicuous non-native species often need several lines of evidence to piece together invasion histories (Geller et al., 1997; Saltonstall, 2002; 
Blakeslee et al., 2008; Geller et al., 2010). As such, it might take years or even centuries before ambiguous invasions can be properly resolved or at least better understood (e.g., Ruiz et al., 2000; Wonham \& Carlton, 2005; Brawley et al., 2009).

The recent discovery of the globally invasive European green crab, Carcinus maenas (Linnaeus, 1758), in Newfoundland, Canada (Best et al., 2009; McKenzie et al., 2010) is one of these problematic cases. The crab is widespread throughout the North Atlantic, with several viable vectors, and at present is found on almost every continent across the globe (Carlton \& Cohen, 2003). Its first non-native record is from the early 19th century in the north-eastern United States (Say 1817), where it was probably transported via rock ballast or hull fouling (Behrens Yamada, 2001). Over the next 100 years, the crab spread north through the Gulf of Maine, finally reaching the Canadian border in 1951. Populations spread around the Bay of Fundy and southeastern Nova Scotia in the 1960s and were eventually observed in north-eastern Nova Scotia in the 1990s (Carlton \& Cohen, 2003). Initially, it appeared as if the north-eastern populations were the result of a range expansion from the south (Audet et al., 2003); however, Roman (2006) discovered that the northern populations were actually from a cryptic secondary introduction event, probably originating from northern Europe. Carcinus maenas was thus able to bypass a challenging advection obstacle (i.e., predominantly southerly alongshore currents) to successfully establish in north-eastern Canada (Pringle et al., in prep.).

While now found throughout much of the Canadian Maritimes, the green crab had been absent from coastal waters of Newfoundland until recently. In August 2007, a mixed population of juvenile and adult crabs was discovered in North Harbour (NH), Placentia Bay, in south-eastern Newfoundland (Klassen \& Locke, 2007). According to fishermen accounts [reported to Canadian Department of Fisheries and Oceans (DFO) officials], crabs similar in appearance had been observed for c. 4 years prior to these official records. More extensive surveys conducted in September 2007 detected crabs at several other Placentia Bay sites, sometimes in high abundance (McKenzie et al., 2007).

Based on this evidence, the green crab has likely been in Newfoundland for several years, yet how it arrived and where it came from remains unclear. It is unlikely that the colonization occurred via natural current-driven dispersal from eastern Nova Scotia because ocean circulation is dominated by the southwest-ward flow from the Gulf of St. Lawrence and Newfoundland shelf (Han et al., 1999); thus crab larvae would be carried in the wrong direction. Alternatively, numerous human activities might have transported the crab, such as commercial shipping, recreational boating or fishing, as these are all active, potential vectors into Newfoundland waters. Resolving source populations for the introduction is also complicated by the crab's invasion history in the north-west Atlantic (NWA) - C. maenas has had at least two introduction events from Europe (Roman, 2006), and its successful establishment in the eastern United States and Atlantic Canada provide numerous sources for intracoastal anthropogenic movements. Thus, there are two probable source regions: the crab's native European range or introduced populations from the NWA.

Genetic tools are useful in resolving invasion histories, helping to determine likely source locations and suggesting natural or anthropogenic vectors (Roman, 2006; Blakeslee et al., 2008; Darling et al., 2008; Geller et al., 2010). As such, we analysed genetic data from European and NWA populations to determine the probable source and vector for the Placentia Bay introduction using multiple loci from mitochondrial and microsatellite nuclear genes. We also obtained demographic data and shipping records for Placentia Bay to determine whether congruent patterns existed with our genetic analyses - shown to be an effective paired analysis in other studies (e.g., Brawley et al., 2009).

\section{METHODS}

\section{Sampling}

\section{North Atlantic sampling}

Our NWA data come from sampling performed 1999-2002 by J.R. (these samples were included in Roman, 2003, 2006) from 34 sites ranging from Louisbourg, Nova Scotia to Freeport, New York (Table 1). For comparison to Europe, we used previously published sequences and distribution data from Roman \& Palumbi (2004) collected during the years 19992001 from 14 sites ranging from Trondheim, Norway, to Palmones, Spain, and including the British Isles, Faeroe Islands and Iceland. Our study focuses on NWA and European samples collected during the years 1999-2002 because crabs sampled during this period would most closely represent potential predecessors for the population(s) of crabs found in Newfoundland. Fish harvesters reported finding the crab in Placentia Bay for $c$. 4 years prior to the first official reporting in 2007 (McKenzie, pers. comm.), and studies conducted in Placentia Bay in 1997-99 on juvenile cod in eel grass beds (Robichaud \& Rose, 2006; Robichaud, pers. comm.) and in 2002 on rock crab (Cancer irroratus) (DFA 2002) found no indication of green crabs. Both sets of information conservatively suggest that $C$. maenas was unlikely to have been present in Newfoundland prior to 2002; thus, samples from 1999 to 2002 likely include individuals that directly contributed to initial founding populations in Placentia Bay.

\section{Newfoundland surveys and sampling}

A province-wide aquatic invasive species survey was conducted in September 2007 following the discovery of C. maenas in Placentia Bay (McKenzie et al., 2007; Fig. 1). This survey was led by DFO in collaboration with Memorial University of Newfoundland (MUN) and the Provincial Department of Fisheries and Aquaculture (DFA) (Fig. 1). A combination of methods was used to assess the distribution and abundance 
Table 1 Site information for Europe, north-west Atlantic (NWA) and Newfoundland, including site codes, sample sizes, collection years and population-level genetic diversity ( \pm standard deviation) in terms of haplotypes $(H)$. Regions (bold), subregions (italics) and subdivisions $(>$ ) are also included, and totals (grey shading) are listed at the bottom of each. Numbers in parentheses within microsatellite sample size column are for the collection years 2000 and 2002, separately. European and NWA site information comes from Roman (2003), Roman \& Palumbi (2004), and Roman (2006).

\begin{tabular}{|c|c|c|c|c|c|}
\hline Regions, subregions, and sites & $\begin{array}{l}\text { Site } \\
\text { code }\end{array}$ & $\begin{array}{l}\text { Collection } \\
\text { year }\end{array}$ & $\begin{array}{l}\text { mtDNA } \\
\text { sample size }(n)\end{array}$ & $\begin{array}{l}\text { Microsatellite } \\
\text { sample size }(n)\end{array}$ & $\begin{array}{l}\text { Haplotype } \\
\text { diversity }(H)\end{array}$ \\
\hline \multicolumn{6}{|l|}{ Europe Region } \\
\hline Palmones, Spain & PAL & 2000 & 10 & & $0.93 \pm 0.07$ \\
\hline Cádiz, Spain & $\mathrm{CAD}$ & 2001 & 12 & & $0.85 \pm 0.07$ \\
\hline Aveiro, Portugal & AVE & 2001 & 24 & & $0.81 \pm 0.06$ \\
\hline Bilbao, Spain & BIL & 2001 & 15 & & $0.65 \pm 0.13$ \\
\hline Roscoff, France & ROS & 1999 & 16 & & $0.86 \pm 0.08$ \\
\hline Fowey, UK & FOW & 2001 & 14 & & $0.89 \pm 0.06$ \\
\hline Hoek van Holland, the Netherlands & $\mathrm{HVH}$ & 2001 & 19 & & $0.81 \pm 0.06$ \\
\hline Bremerhaven, Germany & BRE & 2001 & 17 & & $0.87 \pm 0.07$ \\
\hline Göteborg, Sweden & GOT & 2001 & 15 & & $0.93 \pm 0.04$ \\
\hline Oslo, Norway & OSL & 2001 & 9 & & $0.81 \pm 0.12$ \\
\hline Mongstadt, Norway & $\mathrm{MON}$ & 2001 & 24 & & $0.90 \pm 0.05$ \\
\hline Trondheim, Norway & TRO & 1999 & 7 & & $0.95 \pm 0.10$ \\
\hline Tórshavn, Faeroe Islands & FAE & 2001 & 20 & & $0.56 \pm 0.06$ \\
\hline Seltjarnarnes, Iceland & ICE & 2002 & 15 & & $0.00 \pm 0.00$ \\
\hline Regional Total & & & 217 & 0 & $0.88 \pm 0.01$ \\
\hline \multicolumn{6}{|l|}{ NWA Region } \\
\hline \multicolumn{6}{|c|}{ United States/original introduction subregion } \\
\hline Freeport, New York & FRE & 1999 & 17 & & $0.23 \pm 0.13$ \\
\hline Rye, New York & RYE & 2002 & 10 & 9 & $0.00 \pm 0.00$ \\
\hline Barnstable, Massachusetts & BAR & 2002 & 20 & 18 & $0.00 \pm 0.00$ \\
\hline Winthrop, Massachusetts & WIN & 2000 & 11 & & $0.00 \pm 0.00$ \\
\hline Nahant, Massachusetts & $\mathrm{NAH}$ & 1999,2002 & 31 & 21 & $0.00 \pm 0.00$ \\
\hline Isles of Shoals, Maine & $\mathrm{SHO}$ & 2002 & 20 & 19 & $0.10 \pm 0.09$ \\
\hline Chebeaugue, Maine & $\mathrm{CHB}$ & 2002 & 19 & & $0.00 \pm 0.00$ \\
\hline New Harbor, Maine & NEW & 2002 & 19 & & $0.11 \pm 0.09$ \\
\hline Searsport, Maine & SEA & 2001, 2002 & 33 & 15 & $0.12 \pm 0.07$ \\
\hline Schoodic, Maine & $\mathrm{SCH}$ & 2002 & 31 & & $0.06 \pm 0.06$ \\
\hline Lubec, Maine & LUB & 1999, 2002 & 33 & 5 & $0.17 \pm 0.09$ \\
\hline Subregional Total & & & 244 & 87 & $0.07 \pm 0.02$ \\
\hline \multicolumn{6}{|c|}{ Novo Scotia and New Brunswick/admixture zone subregion } \\
\hline \multicolumn{6}{|l|}{$>$ Canadian Bay of Fundy subdivision } \\
\hline Grand Manan Island, New Brunswick & MAN & 2002 & 22 & & $0.33 \pm 0.12$ \\
\hline Chance Harbour, New Brunswick & $\mathrm{CHH}$ & 2000,2002 & 28 & $25(5,20)$ & $0.27 \pm 0.11$ \\
\hline West Quaco, New Brunswick & WQC & 2002 & 20 & & $0.36 \pm 0.13$ \\
\hline Cape Enrage, New Brunswick & ENR & 2002 & 19 & & $0.58 \pm 0.12$ \\
\hline Cape d'Or, Nova Scotia & DOR & 2002 & 19 & & $0.30 \pm 0.13$ \\
\hline Scots Bay, Nova Scotia & SCB & 2001, 2002 & 37 & & $0.16 \pm 0.08$ \\
\hline Port George, Nova Scotia & PTG & 2002 & 20 & & $0.19 \pm 0.11$ \\
\hline Gulliver's Cove, Nova Scotia & GUL & 2000,2002 & 33 & $29(9,20)$ & $0.37 \pm 0.10$ \\
\hline Grosses Coques, Nova Scotia & GRC & 2000,2002 & 34 & & $0.64 \pm 0.07$ \\
\hline Subdivision Total & & & 232 & 54 & $0.37 \pm 0.04$ \\
\hline \multicolumn{6}{|l|}{$>$ Central/western Scotian Shelf subdivision } \\
\hline Cape Sable, Nova Scotia & CPS & 2000,2002 & 33 & 12 & $0.76 \pm 0.03$ \\
\hline Sandy Point, Nova Scotia & SPT & 2000,2002 & 30 & $27(12,15)$ & $0.79 \pm 0.03$ \\
\hline Broad Cove, Nova Scotia & $\mathrm{BRC}$ & 2000,2002 & 37 & 28 & $0.75 \pm 0.03$ \\
\hline Chester, Nova Scotia & $\mathrm{CHT}$ & 2000,2002 & 39 & & $0.77 \pm 0.03$ \\
\hline Halifax, Nova Scotia & HAL & 2000,2002 & 34 & $32(12,20)$ & $0.67 \pm 0.06$ \\
\hline Subdivision Total & & & 173 & 99 & $0.76 \pm 0.01$ \\
\hline
\end{tabular}


Table 1 (Continued).

\begin{tabular}{|c|c|c|c|c|c|}
\hline Regions, subregions, and sites & $\begin{array}{l}\text { Site } \\
\text { code }\end{array}$ & $\begin{array}{l}\text { Collection } \\
\text { year }\end{array}$ & $\begin{array}{l}\text { mtDNA } \\
\text { sample size }(n)\end{array}$ & $\begin{array}{l}\text { Microsatellite } \\
\text { sample size }(n)\end{array}$ & $\begin{array}{l}\text { Haplotype } \\
\text { diversity }(H)\end{array}$ \\
\hline \multicolumn{6}{|c|}{ Eastern Nova Scotia/secondary introduction subregion } \\
\hline Musquodoboit, Nova Scotia & MSQ & 2000 & 10 & \multirow{4}{*}{$30(9,21)$} & $0.78 \pm 0.09$ \\
\hline Murphy's Cove, Nova Scotia & MUR & 2000,2002 & 35 & & $0.70 \pm 0.03$ \\
\hline Torbay, Nova Scotia & TOR & 2000,2002 & 35 & & $0.72 \pm 0.03$ \\
\hline Canso, Nova Scotia & CAN & 2000 & 10 & & $0.73 \pm 0.12$ \\
\hline Guysborough, Nova Scotia & GUY & 2000,2002 & 32 & \multirow{5}{*}{20} & $0.68 \pm 0.06$ \\
\hline Port Hawkesbury, Nova Scotia & PTH & 2000,2002 & 30 & & $0.69 \pm 0.05$ \\
\hline St. Peters, Nova Scotia & SPB & 2000, 2002 & 26 & & $0.67 \pm 0.04$ \\
\hline Louisbourg, Nova Scotia & LOU & 2000,2002 & 29 & & $0.69 \pm 0.02$ \\
\hline Bayview, Nova Scotia & BAY & 2000,2002 & 29 & & $0.65 \pm 0.04$ \\
\hline Subregional Total & & & 236 & 50 & $0.69 \pm 0.01$ \\
\hline Regional Total & & & 885 & 290 & $0.65 \pm 0.01$ \\
\hline \multicolumn{6}{|c|}{ Placentia Bay, Newfoundland Region } \\
\hline Come by Chance, Newfoundland & $\mathrm{CBC}$ & 2007 & 20 & \multirow[t]{2}{*}{26} & $0.73 \pm 0.05$ \\
\hline North Harbour, Newfoundland & $\mathrm{NH}$ & 2007 & 22 & & $0.54 \pm 0.07$ \\
\hline Regional Total & & & 42 & 26 & $0.64 \pm 0.04$ \\
\hline
\end{tabular}
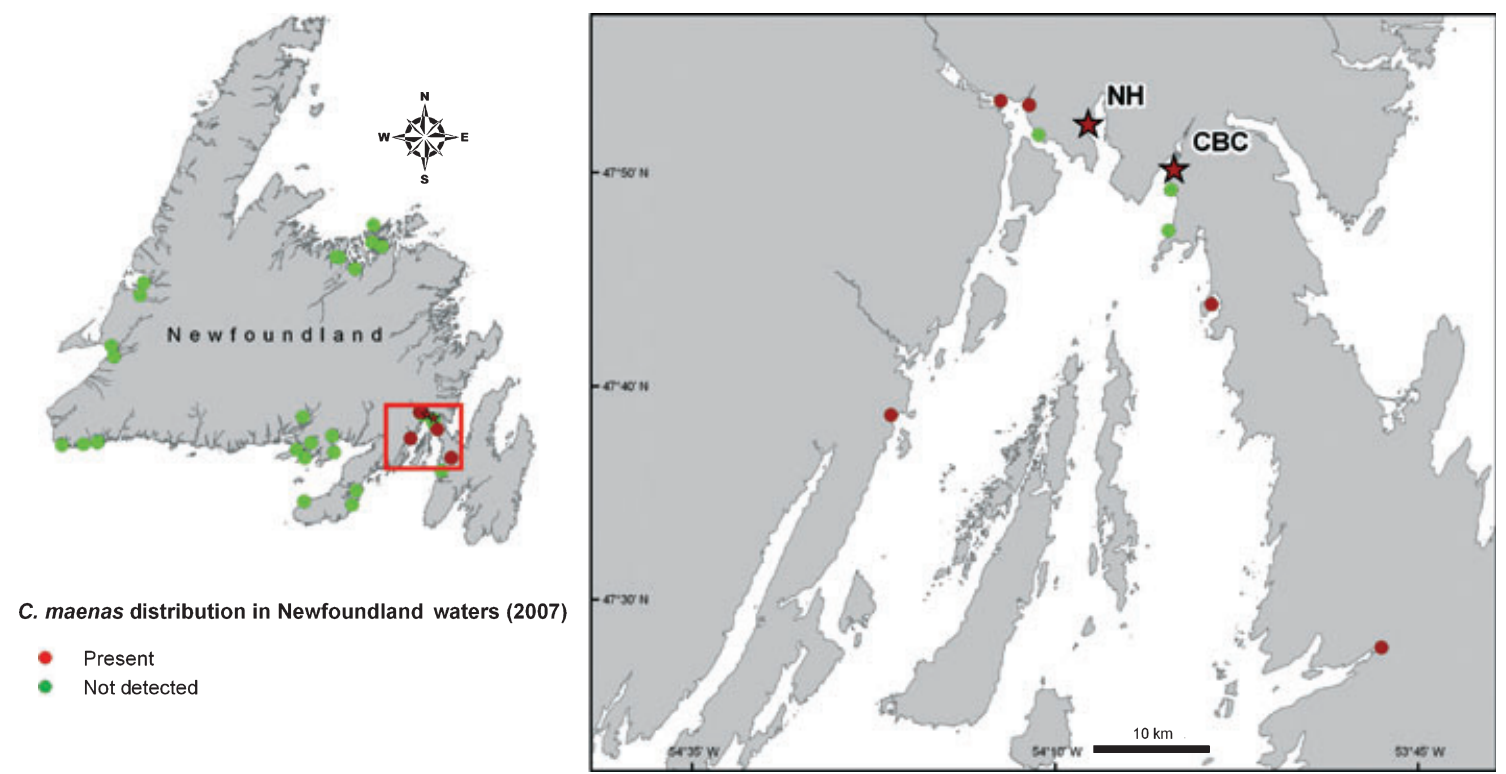

Figure 1 Sample sites for Newfoundland 2007 Aquatic Invasive Species Survey. Sites where Carcinus maenas (Linnaeus, 1758) were present are in red, and those sites where the crab were not detected ${ }^{\star}$ are in green. Stars indicate the sites at North Harbour (NH) and Come by Chance (CBC), where samples were taken for genetic analyses. ${ }^{\star}$ After these surveys, crabs were detected in 2009 at a site on the west coast of Newfoundland in Stephenville (DFO 2010).

of C. maenas in shallow water (1-5 $\mathrm{m}$ depth), including modified whelk pots, shoreline observations, beach seines and SCUBA diver transects. All C. maenas samples were bagged, labelled and immediately frozen. Two sites within Placentia Bay - NH and Come by Chance (CBC) - were selected for genetic analyses (Fig. 1; Table 1) because NH has the highest abundance of $C$. maenas in Placentia Bay with a broad size distribution suggesting a well-established population, and CBC is the closest population to oil and gas refineries (thus a port where vessels may be discharging ballast water).

\section{Genetic analyses}

\section{Mitochondrial sequencing}

NWA and European samples were extracted using a 10\% Chelex solution from gills or muscle tissue of periopods (Roman \& Palumbi, 2004). Newfoundland samples were extracted with a standard cetyl trimethyl ammonium bromide (CTAB) protocol (France et al., 1996) from gill tissues. All samples were amplified and sequenced using a 502-base pair 
fragment of the mitochondrial cytochrome oxidase I (COI) gene with primers and protocols designed for Carcinus (Roman \& Palumbi, 2004), sequenced in both the forward and reverse directions, and aligned (with no gaps) by eye using the program Sequencher 4.8 (Gene Codes Corporation, Ann Arbor, MI, USA). Two hundred and thirty European, 885 NWA and 42 Newfoundland (AY616437-AY616445, DQ523682-DQ523686, HQ129936-HQ129977) samples were included in mitochondrial analyses. ArLequin (Excoffier et al., 2005) was used to estimate genetic diversity indices and levels of population subdivision [analysis of molecular variance (AMOVA)] for NWA, European and Newfoundland populations, as well as to determine genetic relatedness between and among populations (pairwise $\Phi_{\mathrm{ST}}$ ). Pairwise $\Phi_{\mathrm{ST}}$ results were further explored using a multidimensional scaling (MDS) analysis (using Primer 6; Plymouth Marine Laboratory, UK) to look for spatial patterns between and among populations to determine the closest and most dissimilar connections between Newfoundland populations (individually and combined) and NWA and European populations. The closest connections are hypothesized to reveal likely source populations.

\section{Microsatellite analyses}

We genotyped 316 crabs (see Table 1) at microsatellite loci, Cma02EPA, Cma03EPA, Cma04EPA, Cma05EPA, Cma07EPA, Cma08EPA, Cma09EPA and Cma14EPA. Previously described annealing temperatures and PCR conditions (Tepolt et al., 2006) were adopted, with the exception of Cma08EPA $\left(60^{\circ} \mathrm{C}\right.$ annealing temperature). Amplified products were sized on an ABI 3730xl DNA Analyzer, and raw data were analysed using Genemarker v.1.60 (SoftGenetics, LLC, State College, PA, USA). Samples failing to amplify at three or more loci after two attempts were dropped from the data set; unfortunately, limits to DNA quality and quantity precluded amplification from all individuals in the mitochondrial analysis. We successfully genotyped 290 individuals from 19 NWA collections (14 sites, five of which were sampled in both 2000 and 2002) and 26 individuals from Placentia Bay, Newfoundland. Because European populations were excluded as direct sources for the Newfoundland introduction (see mitochondrial results), we did not include them in microsatellite analyses.

We adopted two methods to determine the most likely source(s) for the Newfoundland invasion. First, we utilized Bayesian inference in structure v.2.2 (Falush et al., 2003), which predicts the population structure in the absence of a priori information on the spatial distribution of individuals by grouping genotypes into panmictic population clusters. We assessed likelihoods for models with the number of clusters ranging from $K=1$ to $K=8$, conducting five independent Markov Chain Monte Carlo runs at each value of $K$. For each run, $10^{4}$ generations were discarded as burn-in followed by $10^{5}$ generations of data collection. Given independent sources for the two invasion fronts in the Canadian Maritimes, we adopted a model with uncorrelated allele frequencies while allowing for admixture. To determine the value of $K$ best representing the true population structure, we employed the method of Evanno et al. (2005). We subsequently assessed the probability of coancestry of Newfoundland crabs in each of the predicted clusters to determine likely sources. In addition, we conducted assignment tests using the software GENECLAss2 (Piry et al., 2004) based on the frequencies-based method of Paetkau et al. (1995). All 2000 and 2002 collection sites outside of Newfoundland were included as potential source populations. Assignments were made both for the Newfoundland population as a group and for individual crabs; probabilities for individual assignments were calculated through Monte Carlo resampling of 1000 simulated individuals.

We estimated the effective number of founders (the number of breeding individuals) establishing the Newfoundland population using the software NFCONE (Anderson \& Slatkin, 2007), which simulates the coalescent to estimate the likelihood of the number of ancestral founder lineages sampled from a known source. Based on assignment test results, we clustered crabs from populations comprising the most likely source area and used Placentia Bay individuals to represent the founding population. Simulations were run for $10^{5}$ Monte Carlo repetitions for founding populations ranging in size from 2 to 200 individuals - preliminary simulations suggested 200 as a reasonable upper limit. Time since colonization was set at five generations, and the intrinsic rate of population growth was set at $r=0.5$. Effective number of founding lineages was computed by importance sampling from the generated probability distribution (20,000 Monte Carlo repetitions).

\section{Newfoundland vessel traffic and ballast data}

Shipping and vessel traffic information was obtained from ballast-water exchange reports provided by the Transport Canada National Ballast Water Database (focused on the 2005 and 2007 shipping seasons; data from prior years were not available) and the Eastern Canada Vessel Traffic Services, a database maintained by the Canadian Coast Guard (data included the years 2004-05). These data along with several east coast shipping and ballast-water risk reports, which had been assessed for a Newfoundland alternate ballast-water exchange zone study in McKenzie et al. (2010), were reviewed and compared with likely source populations determined in genetic analyses.

\section{RESULTS}

\section{Placentia Bay demographic data}

$\mathrm{NH}$ and $\mathrm{CBC}$ C. maenas displayed differences in abundance and size frequencies. $\mathrm{NH}$ crabs were more abundant and showed evidence of several size classes or cohorts, suggesting an established population, likely part of the system for several years (Fig. 2). The CBC population was less abundant, and smaller-size classes were most frequent. In native regions, 

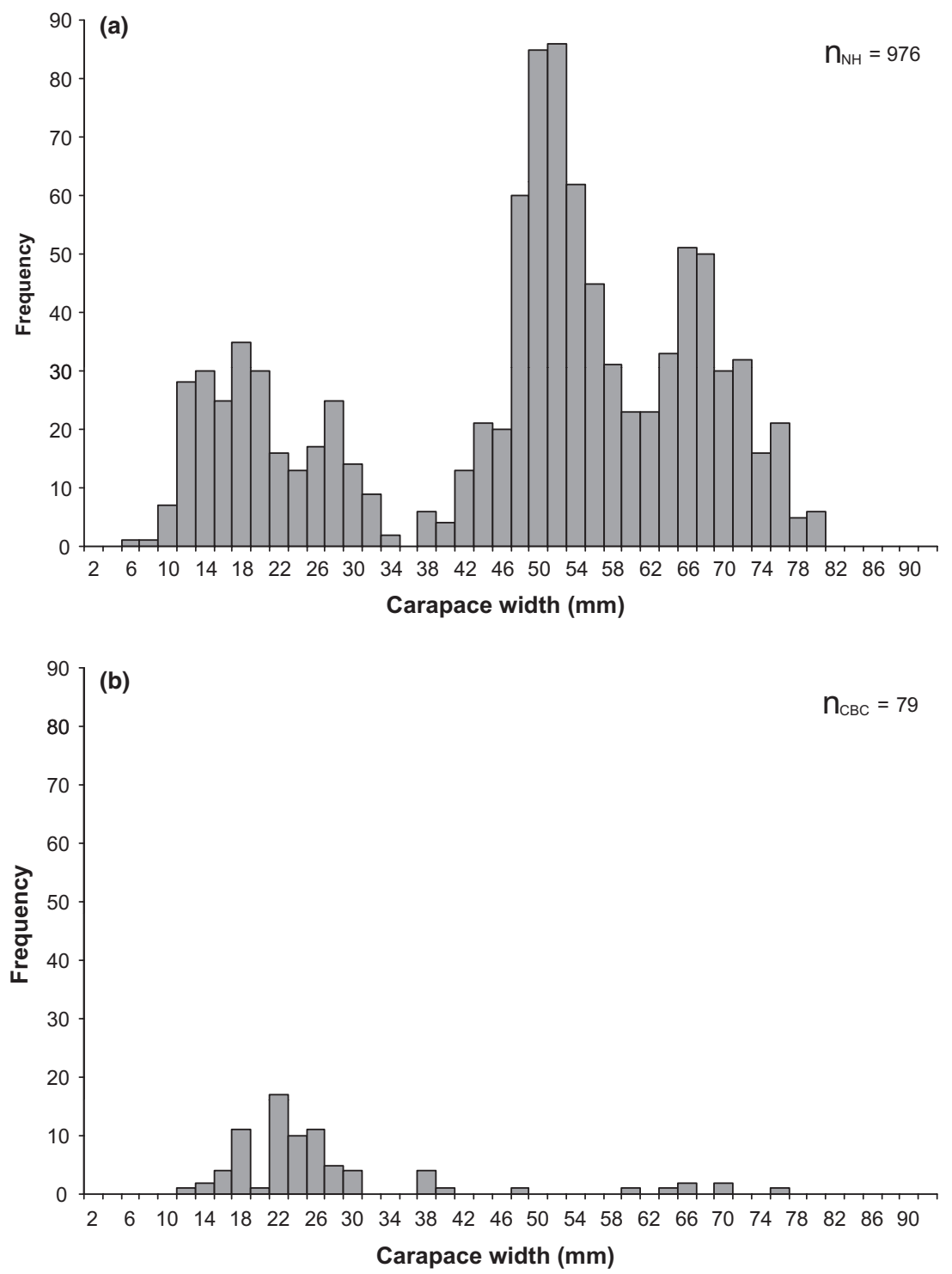

Figure 2 Size frequency distributions for Carcinus maenas (Linnaeus, 1758) crabs from the two Placentia Bay populations, (a) North Harbour (NH) and (b) Come by Chance (CBC). Sizes are based upon crab carapace width $(\mathrm{CW})$.
C. maenas typically attains a size of $c$. 20- mm carapace width (CW) in its first year and increases in size by c. 20-33\% per moult, likely once per year after maturity (Klein Breteler, 1975). Thus, roughly, crabs could be c. $45-70 \mathrm{~mm} \mathrm{CW}$ by their fifth year (when rounding to intervals of $5 \mathrm{~mm}$ using 20$33 \%$ increases per moult). Based on this size-age correlation, the largest C. maenas (> $70 \mathrm{~mm} \mathrm{CW}$ ) observed in both populations, but especially $\mathrm{NH}$, indicate that the crabs could be at least 5 years old, and if the founding population included small juveniles, this would date the introduction to c. 2002. It is important to note, however, that growth data are temperature dependent and crabs will grow slower in colder waters; thus Newfoundland crabs may deviate a bit from these size-age correlations. On the whole, these data suggest that C. maenas has been present in Placentia Bay for several years, and size frequency distributions (Fig. 2) suggest that $\mathrm{NH}$ is well established and possibly an older population than CBC.

\section{Mitochondrial analyses}

Sixty-four haplotypes were found among 1144 crabs in all three regions. Here, we focus on comparisons between Newfoundland and the other two regions (see Roman, 2006 for Europe versus NWA comparisons). Sixty-one haplotypes were observed in Europe, 10 in NWA and four in Placentia Bay. All four Newfoundland haplotypes were a subset of NWA haplotypes (Fig. 3, see Table S1 in Supporting Information). AMOVA analyses suggest significant differentiation of individuals within- and among populations and among regions when all individuals, sites and regions are included. However, when independently compared, NWA and Newfoundland regions were not significantly differentiated (FCT $P=0.606$ ), while comparisons between Europe and Newfoundland were marginally differentiated (FCT $P=0.088$ ). These results suggest a closer connection (less differentiation) between Newfoundland and NWA as opposed to Newfound- 


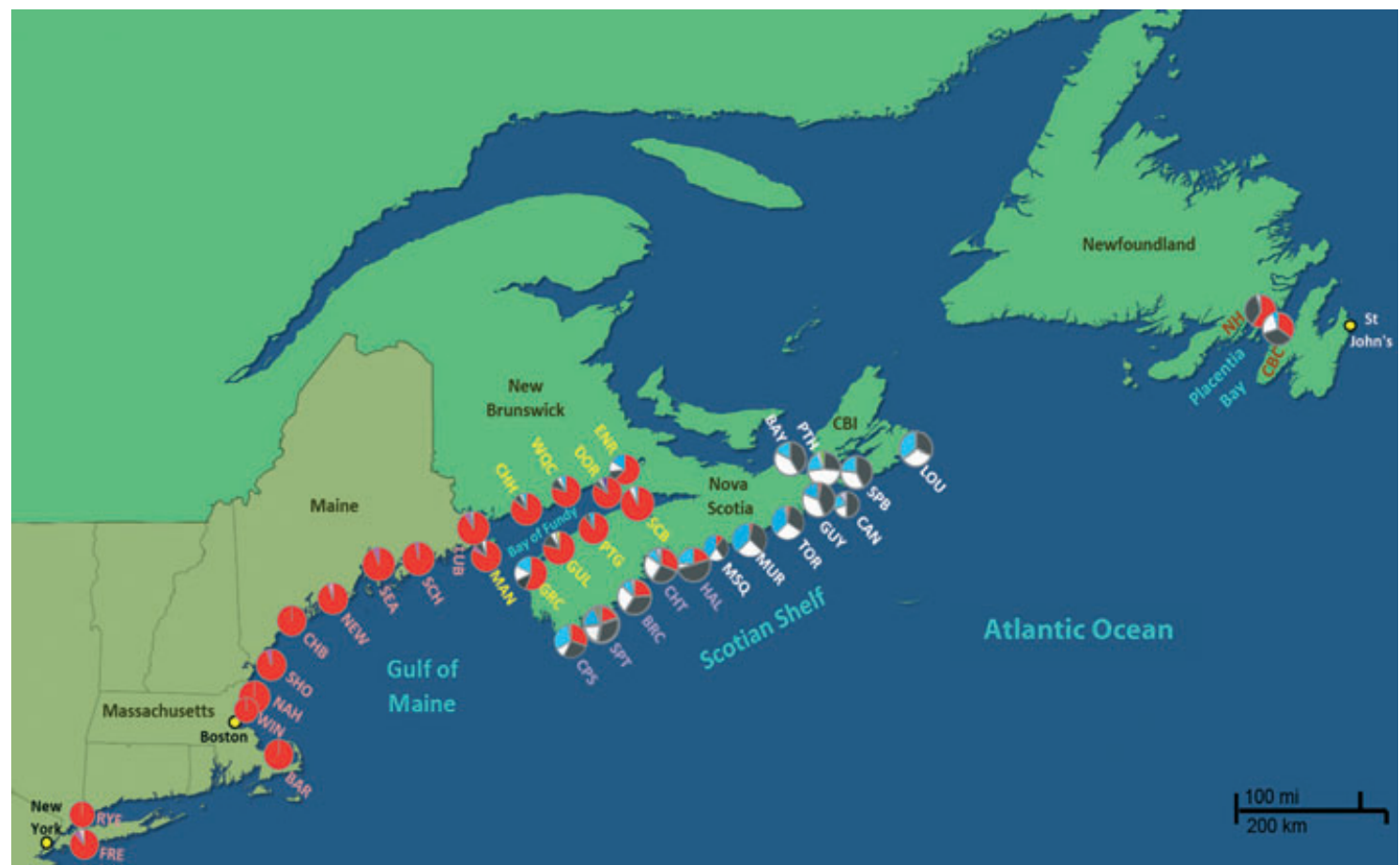

Figure 3 North-west Atlantic (NWA) and Newfoundland sites and haplotype frequency diagrams (pie charts) for populations collected between 1999 and 2002 for the NWA and 2007 for the recent Newfoundland introduction. Pie charts are relatively sized based on sample size within a site. See Table 1 for site information for each of these populations, and Supplemental Table S1 for population-level haplotype identities and frequencies for each site.

Table 2 AMOVA table of differentiation indices for the mitochondrial data for various regional, subregional and subdivision comparisons of north-west Atlantic (NWA) and NEA populations to the NFLD introduced populations. Values in bold are significant at $P<0.05$.

\begin{tabular}{lccr}
\hline & \multicolumn{3}{l}{ Differentiation indices } \\
\cline { 2 - 4 } Comparison & FST & FSC & \multirow{2}{*}{ FCT } \\
\hline Regional & & & \\
EUR vs. NWA vs. NFLD & $\mathbf{0 . 3 0 6}$ & $\mathbf{0 . 2 6 9}$ & $\mathbf{0 . 0 5 1}$ \\
NWA vs. NFLD & $\mathbf{0 . 2 7 2}$ & $\mathbf{0 . 3 1 6}$ & -0.064 \\
EUR vs. NFLD & $\mathbf{0 . 2 0 1}$ & $\mathbf{0 . 1 3 9}$ & $0.072^{*}$ \\
Subregional & & & \\
Original introduction (US) vs. NFLD & $\mathbf{0 . 5 4 0}$ & -0.0009 & $\mathbf{0 . 5 4 1}$ \\
Admixture zone vs. NFLD & $\mathbf{0 . 1 4 4}$ & $\mathbf{0 . 1 6 4}$ & -0.024 \\
Second introduction & $\mathbf{0 . 1 7 3}$ & -0.006 & $\mathbf{0 . 1 7 8}$ \\
$\quad$ (E Nova Scotia) vs. NFLD & & & \\
Admixture zone subdivisions & & & \\
Canadian Bay of Fundy vs. NFLD & $\mathbf{0 . 1 9 5}$ & $\mathbf{0 . 0 3 1}$ & $\mathbf{0 . 1 6 9}$ \\
Central/western Scotian shelf vs. NFLD & $\mathbf{0 . 0 4 9}$ & $\mathbf{0 . 0 3 5}$ & 0.014 \\
Central/western Scotian shelf vs. CBC & $\mathbf{0 . 0 0 7}$ & $\mathbf{0 . 0 3 4}$ & -0.029 \\
\hline
\end{tabular}

CBC, Come by Chance.

${ }^{\star}$ Marginally significant, $P<0.10$.

land and Europe (Table 2). In addition, Newfoundland's genetic diversity $(H=0.64 \pm 0.04)$ is relatively high and not different from NWA's genetic diversity $(H=0.65 \pm 0.01)$, while both are somewhat lower than Europe's genetic diversity $(H=0.88 \pm 0.01)$ (Table 1$)$.

Our haplotype map (Fig. 3) clearly demonstrates the division of NWA populations into three distinct subregions: (1) the original 1800s introduction subregion (US populations); (2) an admixture zone where haplotypes from the two introduction events have mixed (Canadian Bay of Fundy and central/western Scotian Shelf populations); and (3) the secondary late-1900s introduction subregion (eastern Nova Scotian populations). As described, regional-level AMOVA analyses suggest a closer connection between NWA and Newfoundland. However, when analysed at a finer scale, only subregion 2 (the admixture zone) was not significantly differentiated (FCT $P=0.477$ ) from Newfoundland. When further subdivided into Canadian Bay of Fundy and central/western Scotian shelf groups, the Canadian Bay of Fundy was significantly differentiated from Newfoundland (FCT $P=0.014$ ), while the central/western Scotian Shelf was not (FCT $P=0.185)$, which was especially true for $\mathrm{CBC}$ (FCT $P=0.709)$ (Table 2).

Pairwise comparisons of haplotype frequencies also suggest the admixture zone as the likely source area for the Newfoundland introduction when the two Placentia Bay populations were both combined and explored independently (see Table S2). Our MDS plot demonstrates a clear separation of the NWA into distinct subregions (Fig. 4), and the two Newfoundland populations aligned themselves more closely with Nova Scotian populations than either Europe or the 


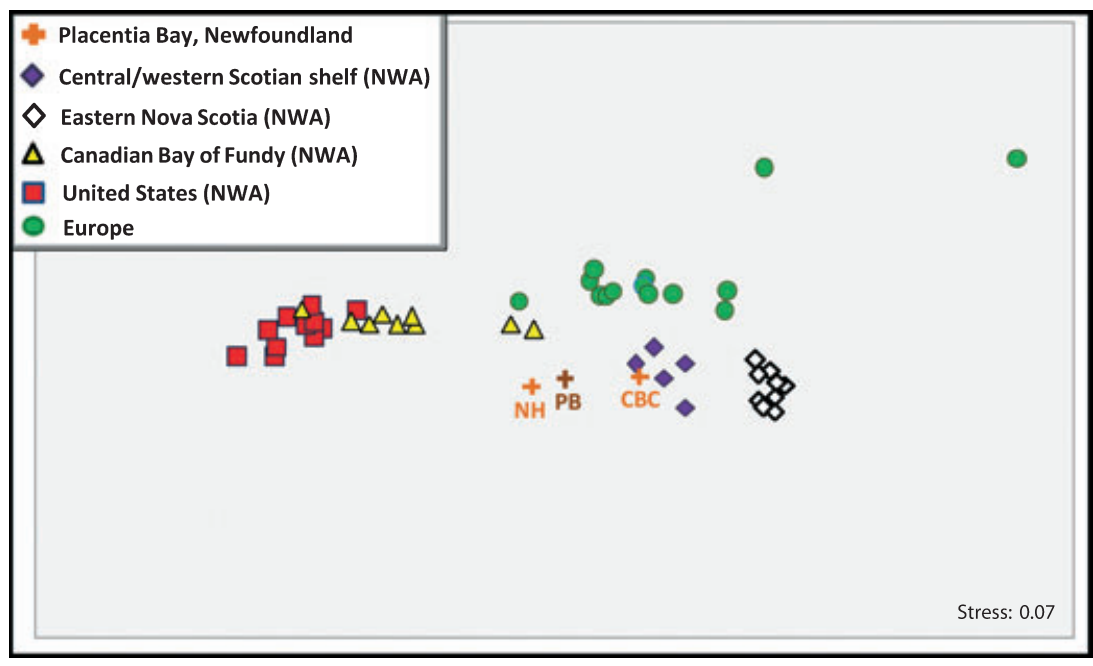

Figure 4 Multidimensional scaling plot of pairwise $\Phi_{\mathrm{ST}}$ values for Carcinus maenas (Linnaeus, 1758) in Europe, north-west Atlantic (NWA) and Placentia Bay (PB), Newfoundland. Newfoundland includes a combined Placentia Bay population (in dark orange) and individual populations (in lighter orange), Come by Chance (CBC) and North Harbour (NH). Overall, the Placentia Bay populations are spatially closest to central/western Scotian shelf populations, and this connection is especially strong for $\mathrm{CBC}$.
United States, and this was especially true for $\mathrm{CBC}$, which is located among central/western Scotian Shelf populations, like Halifax.

\section{Microsatellite analyses}

Bayesian inference of population structure for Newfoundland and NWA strongly supports a model with two genetically differentiated populations (Fig. 5a). Crabs collected from the United States and New Brunswick were uniformly assigned to cluster 1 (overall proportional membership $=0.94$ ), and crabs from eastern Nova Scotia assigned strongly to cluster 2 (Fig. 5b); these clusters reliably correspond to the two historical invasions in the early 1800 s and late 1900s. In contrast, individuals collected from intervening sites in the central/western Scotian Shelf displayed various levels of mixed ancestry between clusters 1 and 2, consistent with admixture between the two historical introductions. Similarly, crabs from Newfoundland also showed mixed ancestry. Mean coancestry of Newfoundland crabs in clusters 1 and 2 was 0.46 and 0.54 , respectively, while mean coancestry of central/western Scotian Shelf crabs was 0.31 and 0.69 , respectively (Fig. 5c).
Group-level assignment tests indicated that the most probable origin for Newfoundland genotypes was Cape Sable (99.84\% probability), followed by Broad Cove $(0.16 \%)$, both of which are found along the central/western Scotian Shelf. This is broadly consistent with individual assignments, where highest probability source populations were within the admixture zone $80 \%$ of the time (Table 3), although in these analyses Broad Cove was most frequently recognized as the highest probability source ( 9 out of the 26 Newfoundland individuals). Finally, an estimate of the effective number of founders establishing Placentia Bay was found to be 30 crabs (30.2), with $95 \%$ confidence intervals of $18.7-57.0$ crabs.

\section{Vessel traffic/ballast data}

\section{National data}

In our analyses of shipping traffic between the Maritime Provinces and Placentia Bay via the Transport Canada National Ballast Water Database, we found major source locations for vessels entering $\mathrm{CBC}$ (the only Placentia Bay destination in the database) from the following Maritime

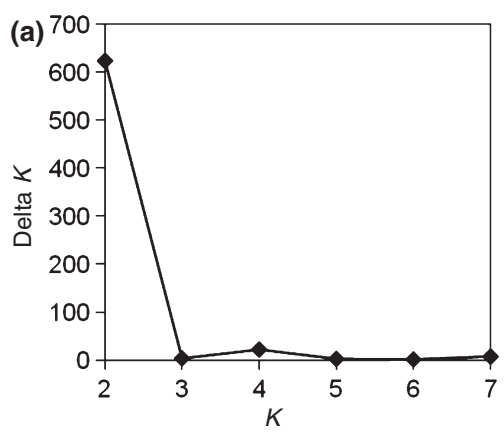

(b)

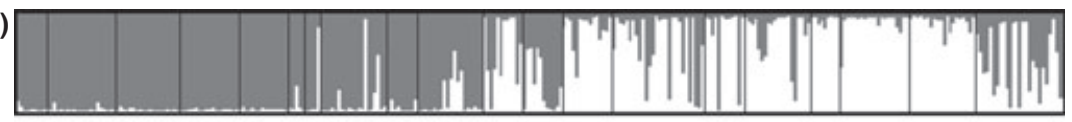

(c)

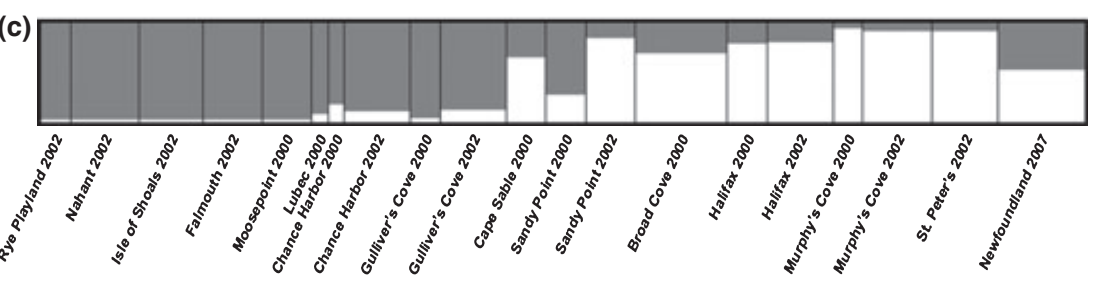

Figure 5 Results of Bayesian clustering analysis. (a) Plot of $\Delta K$ versus $K$ indicating that models with number of clusters $K=2$ are best supported by the data. (b) Individual assignment of crabs to one of $K=2$ clusters (grey and white shading). Each individual is represented by a vertical line divided into two segments indicating proportional membership in the two clusters. (c) Group assignments, indicating mean proportional membership in $K=2$ clusters (grey and white shading). Width of bars representing groups is scaled to sample. 
Table 3 Individual assignment tests for microsatellite analysis. For each Newfoundland individual, the probability of assignment $P$ (the probability of an individual with the observed genotype occurring in the potential source population) is shown for the three most likely sources. Assignments to sources in the admixture zone (Cape Sable to Halifax in central/ western Nova Scotia) are indicated in bold ( $80 \%$ of most probable assignments). Site codes and collection year (see Table 1) are listed below each assignment.

\begin{tabular}{|c|c|c|c|c|c|c|}
\hline $\begin{array}{l}\text { NFLD } \\
\text { individual }\end{array}$ & Assignment 1 & $P$ & Assignment 2 & $P$ & Assignment 3 & $P$ \\
\hline 1 & SPT 2002 & 0.553 & HAL 2000 & 0.474 & CHH 2000 & 0.429 \\
\hline 2 & HAL 2002 & 0.540 & CPS 2000 & 0.498 & BRC 2000 & 0.339 \\
\hline 3 & BRC 2000 & 0.330 & CHH 2000 & 0.243 & HAL 2002 & 0.185 \\
\hline 4 & CPS 2000 & 0.627 & BRC 2000 & 0.522 & SPT 2002 & 0.189 \\
\hline 5 & BRC 2000 & 0.592 & CPS 2000 & 0.426 & SPB 2002 & 0.218 \\
\hline 6 & CPS 2000 & 0.282 & BRC 2000 & 0.120 & SPT 2002 & 0.091 \\
\hline 7 & RYE 2002 & 0.066 & СHH 2002 & 0.031 & SHO 2002 & 0.027 \\
\hline 8 & BRC 2000 & 0.793 & CPS 2000 & 0.383 & HAL 2002 & 0.255 \\
\hline 9 & MUR 2002 & 0.478 & SPT 2002 & 0.423 & MUR 2000 & 0.354 \\
\hline 10 & CPS 2000 & 0.840 & BRC 2000 & 0.284 & HAL 2002 & 0.273 \\
\hline 11 & LUB 1999 & 0.682 & BAR 2002 & 0.574 & SHO 2002 & 0.474 \\
\hline 12 & BRC 2000 & 0.838 & HAL 2002 & 0.803 & MUR 2002 & 0.731 \\
\hline 13 & HAL 2002 & 0.977 & BRC 2000 & 0.920 & CPS 2000 & 0.852 \\
\hline 14 & GUL 2000 & 0.139 & CPS 2000 & 0.122 & СНH 2000 & 0.113 \\
\hline 15 & CPS 2000 & 0.797 & MUR 2002 & 0.784 & BRC 2000 & 0.765 \\
\hline 16 & BRC 2000 & 0.982 & SPB 2002 & 0.981 & SPT 2002 & 0.971 \\
\hline 17 & HAL 2000 & 0.202 & СHH 2002 & 0.176 & SPT 2002 & 0.123 \\
\hline 18 & HAL 2000 & 0.369 & HAL 2002 & 0.359 & LUB 1999 & 0.302 \\
\hline 19 & BRC 2000 & 0.793 & CPS 2000 & 0.503 & GUL 2000 & 0.347 \\
\hline 20 & СHH 2002 & 0.172 & SPT 2002 & 0.163 & BRC 2000 & 0.159 \\
\hline 21 & BRC 2000 & 0.625 & LUB 1999 & 0.424 & СHH 2000 & 0.349 \\
\hline 22 & CPS 2000 & 0.188 & LUB 1999 & 0.174 & CHH 2002 & 0.168 \\
\hline 23 & SPB 2002 & 0.998 & SPT 2002 & 0.962 & HAL 2002 & 0.953 \\
\hline 24 & HAL 2002 & 0.825 & MUR 2002 & 0.780 & BRC 2000 & 0.744 \\
\hline 25 & BRC 2000 & 0.897 & CPS 2000 & 0.880 & HAL 2002 & 0.876 \\
\hline 26 & BRC 2000 & 0.697 & CPS 2000 & 0.375 & GUL 2002 & 0.346 \\
\hline
\end{tabular}

locations: Dalhousie and Saint John (New Brunswick); and Halifax, Dartmouth, and Point Tupper (Nova Scotia) (see Fig. S1). Saint John, Halifax and Dartmouth are all found within the admixture zone. Consistent with this information, data from the Canadian Coast Guard - Eastern Canada Region database for the 2004-05 shipping season included entries in Placentia Bay for CBC as well as two others, Whiffen Head and Argentia. Vessels travelling to these Newfoundland ports originated from the same four Maritime sites: Dalhousie, Saint John, Halifax and Dartmouth; as well as three additional sites in eastern Nova Scotia: Canso, North Sydney and Sydney.

\section{International data}

In reviewing studies of international shipping data (see review in McKenzie et al., 2010) to Placentia Bay, the ports at CBC, Whiffen Head and Argentia were consistently found to be the most frequented by international shipping traffic. In particular, the majority of vessels (85\%) entering CBC during the 2000 shipping season used water ballast. Tankers make up the majority of ships frequenting CBC; c. 50\% of sampled tankers had conducted ballast exchange in either coastal or oceanic waters. Source locations for ships discharging ballast in Newfoundland waters were primarily from the north-eastern United States (Carver \& Mallet, 2002). In addition, international shipping data provided by Transport Canada for traffic entering 18 Newfoundland ports in 2003 listed 646 vessels from 43 different locations (five different continents). CBC received a large number of these international vessels $(n=111)$, and most $(52 \%)$ had travelled from North American ports, primarily the eastern United States (McKenzie et al., 2010).

\section{DISCUSSION}

Prior to human influence, marine dispersals were constrained by natural forces such as oceanic and coastal currents and the various associated challenges for successful settlement and establishment (e.g., finding suitable habitat and avoiding Allee effects). Currently, anthropogenic global transport, which is often associated with enhanced propagule pressure (e.g., via multiple introduction events), has allowed species to circumvent these obstacles and move to locations that were once challenging or near impossible to access (Ruiz et al., 1997; Wilson et al., 2009).

In the NWA, C. maenas has overcome the difficulties of advective dispersal via anthropogenic aid at least twice in the past 20 or 30 years. The first event was in the late 20th century, when a secondary introduction to the Canadian Maritimes allowed the crab to overcome advective downstream currents impacting northward range expansion from the United States (Roman, 2006). The second event is the Newfoundland introduction documented here. South-eastern Newfoundland is geographically quite distant from easternmost locations in 
Nova Scotia (c. $450 \mathrm{~km}$ ), and source populations from the central/western Scotian Shelf are even farther (c. $800 \mathrm{~km}$ from Halifax to Placentia Bay). Moreover, the ocean circulation along the Scotian Shelf is dominated by a southwest-ward flow of water from the Gulf of St. Lawrence and the Newfoundland shelf (Han et al., 1999; Han \& Loder, 2003; Han et al., 2008), so any naturally dispersing larvae would actually be pushed downstream away from Newfoundland. In short, the overall mean flow would not be able to transport larvae from Nova Scotia to Newfoundland. Anthropogenic transport, however, has easily and repeatedly transcended this barrier allowing C. maenas to establish Placentia Bay.

\section{Determining source and timing of introduction}

Our results strongly suggest a NWA and particularly Nova Scotian origin for the Newfoundland populations of C. maenas rather than a direct introduction from Europe. Specifically, source populations for the Newfoundland introduction likely came from an area in Nova Scotia characterized by a mixture of diversity from the 19th- and 20th-century introduction events to North America. These populations exhibit mixed ancestry at nuclear microsatellite and mitochondrial loci between two well-defined population clusters reflecting both the earlier and later introductions (Figs 3-5). In particular, several mitochondrial analyses (Table 2, Fig. 4, see Table S2) suggest the central/ western Scotian Shelf (Halifax to Cape Sable) to be the most likely source area, especially for $\mathrm{CBC}$, which can be clearly located within the cluster of these Scotian populations. Assignment tests for microsatellite data also consistently specify collection sites in this admixture zone as the most probable sources (Table 3), and individual crabs show distinct signatures of genetic admixture not observed in either eastern Nova Scotia, New Brunswick or the United States (Fig. 5). Although an introduction from the admixture zone appears the most plausible explanation for our results, we cannot definitively rule out an alternative hypothesis for multiple introductions from northern and southern NWA populations followed by in situ admixture (essentially resulting in Placentia Bay populations that 'mimic' the genetic composition of the admixture zone). This explanation is clearly less parsimonious than an introduction from the admixture zone, especially considering the presence of major ports, such as Halifax, within the area and congruent patterns in our molecular markers.

Although analyses of both mitochondrial and nuclear genetic loci indicate admixture between the two NWA invasion fronts, there appear to be differences between the two marker systems in terms of the geographic extent of the admixture zone. Specifically, mitochondrial data suggest that genetic introgression from the more recently introduced, northern C. maenas population has extended well into the western Bay of Fundy (Fig. 3). In contrast, microsatellite data show very little evidence of admixture at northern Bay of Fundy sites, and introgression of north-eastern Nova Scotian alleles is low even at sites along the southern Bay of Fundy (Fig. 5). Recent analyses suggest that the mitochondrial admixture zone continues to shift as prevailing currents drive larval recruitment primarily to the southwest (Pringle et al., in prep.), and these dynamics should be expected to result in similar shifts at nuclear loci. However, theoretical models (supported by a substantial body of empirical evidence) have shown that maternally inherited alleles are likely to introgress more rapidly than those that are biparentally inherited, particularly in cases of hybridization between populations with unequal densities (Chan \& Levin, 2005; Wirtz, 1999).

Finally, a slight but discernable difference in haplotype frequencies was detected between the two Placentia Bay populations. More specifically, pairwise comparisons of haplotype frequencies demonstrated probable source matches for Placentia Bay from the central/western Scotian Shelf (Fig. 4). However, this trend was much stronger when $\mathrm{CBC}$ was independent of $\mathrm{NH}$, possibly suggesting differing source vectors, source locations or timing of introduction between the populations; in addition, demographic data might also support NH as an older population (Fig. 2). On the other hand, given the geographic and genetic closeness between $\mathrm{NH}$ and $\mathrm{CBC}$, this difference might simply be owing to sampling more sampling could result in greater haplotypic convergence between the two populations. Regardless of whether we group these populations or not, our mitochondrial results still suggest that the Nova Scotian admixture zone is the most likely source area for the Newfoundland invasion.

\section{Probable vectors}

Many vectors have been responsible for the numerous introductions of C. maenas that have occurred globally, including vessel traffic and shipping (e.g., fishing vessels and gear, solid and water ballast, hull fouling); accidental transport with target aquaculture species; live seafood and baitworm trades; and aquaria escapees (Carlton \& Cohen, 2003). The latter two are not currently active vectors between Newfoundland and Nova Scotia, and the movement of aquaculture products between provinces is monitored and subject to introduction and transfer regulations, making this a less likely vector as well (McKenzie, pers. comm.). This therefore leaves vessel traffic and shipping as the most likely vector candidates for the Newfoundland introduction.

Placentia Bay is one of the busiest bays in Newfoundland with multiple users, including commercial shipping, commercial and recreational fishing and recreational vessels. Presently, no regulations require commercial ships to exchange ballast when travelling between Canadian ports (Canada Shipping Act 2006, Transport Canada 2007); ballast-carrying ships are thus a highly likely vector for the Newfoundland introduction, especially given the strong connection we found in our shipping analyses between the Scotian Shelf (including Halifax) and $\mathrm{CBC}$ (see Fig. S1). CBC has the only oil refinery in Newfoundland, with the capacity to process more than 100,000 barrels of oil a day, making it a heavily utilized port for ballastcarrying ships, including those originating in the admixture zone. Furthermore, a recent Canadian risk assessment (to 
establish alternate ballast exchange zones for the Newfoundland and Labrador region) expressed concern that current shipping practices, and specifically ships originating from the Canadian Maritimes and North-eastern United States may be responsible for present and future introductions of aquatic invasive species to Newfoundland (McKenzie et al., 2010). Even though ballast-carrying ships are a highly probable introduction vector for Placentia Bay, we cannot dismiss the potential role of fishing and recreational vessels as alternative vectors, since such vessels have been found to inadvertently carry hitchhiking species on boats or fishing gear (Darbyson, 2006; Klassen \& Locke, 2007). It is therefore possible that multiple vectors contributed to the spread of C. maenas to Newfoundland.

\section{CONCLUSION}

Carcinus maenas continues to expand its global reach, and efforts to control its movements have yet to halt its momentum. In Newfoundland, mitigation and eradication attempts have only had marginal success. In 2008 and 2009, several Newfoundland organizations - DFO, DFA, MUN and local fish harvesters with the Fish Food and Allied Workers union conducted experimental mitigation harvesting activities in $\mathrm{NH}$. In 2008 , more than 25,000 pounds, or c. 350,000 individual green crabs, were removed via harvesting in 20 days. Unfortunately, even with mitigation attempts, C. maenas has continued to spread to new areas of Placentia Bay, and valuable eelgrass beds and local fisheries have become threatened (DFO 2010). The crab has even extended its invasive range far from Placentia Bay: in 2009, C. maenas individuals were discovered along the western Newfoundland coast (DFO 2010). Such continued anthropogenic movement around the island poses considerable risk to other coastal regions.

Although the green crab is highly abundant in many areas of Placentia Bay, our genetic analyses suggest that the invasion could have derived from as few as 30 founding individuals (reflecting effective founder size, not census size, which could have been larger). Despite this substantial population bottleneck associated with Newfoundland colonization, Placentia Bay has relatively high genetic diversity (Table 1), which has also been observed in other invasive green crab populations, including Nova Scotia, South Africa and Australia (Roman \& Darling, 2007). The fact that little diversity has been lost in Placentia Bay compared with source populations (Table 1) may reflect the importance of demographic parameters in determining the diversity of invasive populations; i.e., rapid population increase following initial bottlenecks could allow colonizing populations to avoid significant losses of diversity relative to their sources, a further sign that invasive species need not exhibit characteristics typical of small founding populations (Roman \& Darling, 2007; Wilson et al., 2009). Similar findings in other regions (Tepolt et al. 2009) imply that the species is capable of overcoming relatively extreme population bottlenecks associated with introduction, representing a significant challenge to vector management.
The importance of determining introduction vectors and making appropriate management decisions to reduce the risk of invasion is vital in controlling the impact that this and future invaders can have on the environment and economy around the world. Long-distance dispersal events can greatly increase the range of invasive species, and non-native populations can be important secondary sources of introduction, not only via natural dispersal but also through anthropogenic vectors potentially allowing species to overcome considerable natural barriers and become established in previously unattainable regions (Wilson et al., 2009). As such, measures aimed at preventing these movements should be an immediate priority, or hitchhiking species, particularly those with invasive qualities, can continue to spread and establish in regions across the globe.

\section{ACKNOWLEDGEMENTS}

We thank Kiley Best, Caitlin Hamer, Bob O'Donnell, Phil Sargent, Andrew Vickerson and Terri Wells for field and laboratory help, and the Sloan Foundation's Census of Marine Life for supporting the work. A.M.H.B. thanks Greg Ruiz, Whitman Miller, the Marine Invasions Lab and the Plant Ecology lab at SERC for support and use of facilities. A.M.H.B. also thanks Ray Houghton for graphics assistance.

\section{REFERENCES}

Anderson, E.C. \& Slatkin, M. (2007) Estimation of the number of individuals founding colonized populations. Evolution, 61, 972-983.

Audet, D., Davis, D.S., Miron, G., Moriyasu, M., Benhalima, K. \& Campbell, R. (2003) Geographic expansion of a nonindigenous crab, Carcinus maenas (L.), along the Nova Scotian shore into the southeastern Gulf of St Lawrence, Canada. Journal of Shellfish Research, 22, 255-262.

Behrens Yamada, S. (2001) Global Invader: The European Green Crab. Oregon Sea Grant, Corvallis.

Best, K., McKenzie, C.H. \& Couturier, C. (2009) Early life stage biology of a new population of green crab, Carcinus maenas, in Placentia Bay: implications for mussel culture in Newfoundland. Agriculture Association of Canada Special Publication, 15, 48-50.

Blakeslee, A.M.H., Byers, J.E. \& Lesser, M.P. (2008) Solving cryptogenic histories using host and parasite molecular genetics: the resolution of Littorina littorea's North American origin. Molecular Ecology, 17, 3684-3696.

Brawley, S.H., Coyer, J.A., Blakeslee, A.M.H., Olsen, J.L., Hoarau, G., Johnson, L.E., Byers, J.E. \& Stam, W.T. (2009) Historical invasions of the intertidal zone of Atlantic North America associated with distinctive patterns of trade and emigration. Proceedings of the National Academy of Sciences USA, 106, 8239-8244.

Canada Shipping Act (2006) Ballast Water Control and Management Regulations (SOR/2006-129). Available at: http:/laws.justice.gc.ca/en/SOR-2006-129/ (accessed 15 July 2009). 
Carlton, J.T. \& Cohen, A.N. (2003) Episodic global dispersal in shallow water marine organisms: the case history of the European shore crabs Carcinus maenas and C. aestuarii. Journal of Biogeography, 30, 1809-1820.

Carver, C.E. \& Mallet, A.L. (2002) An assessment of the risk of ballast water-mediated introduction of non-indigenous phytoplankton and zooplankton into Atlantic Canadian waters, Mallet Research Services Ltd., Dartmouth, Nova Scotia.

Chan, K.M.A. \& Levin, S.A. (2005) Leaky prezygotic isolation and porous genomes: rapid introgression of maternally inherited DNA. Evolution, 59, 720-729.

Darbyson, E.A. (2006) Local vectors of spread of the green crab (Carcinus maenas) and the clubbed tunicate (Styela clava) in the southern Gulf of St. Lawrence, Canada. MSc Thesis, Dalhousie University, Halifax, Nova Scotia.

Darling, J.A., Bagley, M.J., Roman, J., Tepolt, C.K. \& Geller, J.B. (2008) Genetic patterns across multiple introductions of the globally invasive crab genus Carcinus. Molecular Ecology, 17, 4992-5007.

DFA (2002) Rock crab surveys conducted - Placentia Bay and Fortune Bay. Fisheries Diversification Program: FDP 358-2. Government of Newfoundland and Labrador. Available at: http://www.fishaq.gov.nl.ca/research_development/fdp/fdp_ 358-2.pdf (accessed 19 February 2010).

DFO (2010) Ecological assessment of the invasive European green crab, Carcinus maenas, in Newfoundland 2007-2009. DFO Canadian Science Advisory Secretariat Proceedings Series, 2010/033.

Evanno, G., Regnaut, S. \& Goudet, J. (2005) Detecting the number of clusters of individuals using the software STRUCTURE: a simulation study. Molecular Ecology, 14, 2611-2620.

Excoffier, L., Laval, G. \& Schneider, S. (2005) Arlequin ver 3.0: an integrated software package for population genetics data analysis. Evolutionary Bioinformatics Online, 1, 47-50.

Falush, D., Stephens, M. \& Pritchard, J.K. (2003) Inference of population structure using multilocus genotype data: Linked loci and correlated allele frequencies. Genetics, 164, 1567-1587.

France, S.C., Rosel, P.E., Agenbroad, J.E., Mullineaux, L.S. \& Kocher, T.D. (1996) DNA sequence variation of mitochondrial large-subunit rRNA provides support for a two subclass organization of the Anthozoa (Cnidaria). Molecular Marine Biology and Biotechnology, 5, 77-86.

Geller, J.B., Walton, E., Grosholz., E. \& Ruiz, G. (1997) Cryptic invasions of the crab Carcinus detected by molecular phylogeography. Molecular Ecology, 6, 256-262.

Geller, J.B., Darling, J.A. \& Carlton, J.T. (2010) Genetic Perspectives on marine biological invasions. Annual Review of Marine Science, 2, 367-393.

Han, G. \& Loder, J.W. (2003) Three-Dimensional seasonalmean circulation and hydrography on the eastern Scotian Shelf. Journal of Geophysical Research, 108, 1-21.

Han, G., Loder, J.W. \& Smith, P.C. (1999) Seasonal-mean hydrography and circulation in the Gulf of St. Lawrence and on the Eastern Scotian and Southern Newfoundland Shelves. Journal of Physical Oceanography, 29, 1279-1301.
Han, G., Lu, Z., Wang, Z., Helbig, J., Chen, N. \& deYoung, B. (2008) Seasonal variability of the Labrador Current and shelf circulation off Newfoundland. Journal of Geophysical Research, 113, C10013.

Klassen, G. \& Locke, A. (2007) A biological synopsis of the European green crab, Carcinus maenas. Canadian Manuscript Report of Fisheries and Aquatic Sciences, 2818, $1-75$.

Klein Breteler, W.C.M. (1975) Laboratory experiments on the influence of environmental factors on the frequency of moulting and the increase in size at moulting of juvenile shore crabs, Carcinus maenas. Netherlands Journal of Sea Research, 9, 100-120.

McKenzie, C.H., Baines, T., Best, K., Boland, R., Dawe, E., Deibel, D., Drover, D., Johnson, E., Kenny, S., Macneill, S., Mouland, D., O’Donnell, R., Park, L., Sargent, P., Vickers, C. \& Vickerson, A. (2007) The European green crab, Carcinus maenas, in Placentia Bay, Newfoundland AIS Survey 2007. Proceedings of Aquatic Invasive Species Newfoundland Workshop. St. John's, NL, November 16, 2007.

McKenzie, C.H., Han, G., He, M., Baines, T. \& Maillet, G. (2010) Alternate ballast exchange zones for the Newfoundland and Labrador region-an aquatic invasive species risk assessment based on oceanographic modeling, ecologically and biologically significant areas and sustainability of fisheries. Aquaculture Canadian Science Advisory Council, CSAS 2010/087.

Paetkau, D., Calvert, W., Stirling, I. \& Strobeck, C. (1995) Microsatellite analysis of population structure in Canadian polar bears. Molecular Ecology, 4, 347-354.

Piry, S., Alapetite, A., Cornuet, J.M., Paetkau, D., Baudouin, L. \& Estoup, A. (2004) GeneClass2: a software for genetic assignment and first-generation migrant detection. Journal of Heredity, 95, 536-539.

Robichaud, D. \& Rose, G.A. (2006) Density-dependent distribution of demersal juvenile Atlantic cod (Gadus morhua) in Placentia Bay, Newfoundland. ICES Journal of Marine Science, 63, 766-774.

Roman, J. (2003) Tracking anthropogenic change in the North Atlantic using genetic tools. $\mathrm{PhD}$ Thesis. Harvard University, Cambridge, MA.

Roman, J. (2006) Diluting the founder effect: cryptic invasions expand a marine invader's range. Proceedings of the Royal Society B: Biological Sciences, 273, 2453-2459.

Roman, J. \& Darling, J. (2007) Paradox lost: genetic variation and the success of aquatic invasions. Trends in Ecology and Evolution, 22, 454-464.

Roman, J. \& Palumbi, S.R. (2004) A global invader at home: population structure of the green crab, Carcinus maenas, in Europe. Molecular Ecology, 13, 2891-2898.

Ruiz, G.M., Carlton, J.T., Grosholz, E.D. \& Hines, A.H. (1997) Global invasions of marine and estuarine habitats by nonindigenous species: mechanisms, extent, and consequences. American Zoologist, 37, 621-632.

Ruiz, G.M., Fofonoff, P., Carlton, J.T., Wonham, M.J. \& Hines, A.H. (2000) Invasions of coastal marine communities in 
North America: apparent patterns, processes, and biases. Annual Review of Ecology and Systematics, 31, 481-531.

Saltonstall, K. (2002) Cryptic invasion by a non-native genotype of Phragmites australis into North America. Proceedings of the National Academy of Sciences USA, 99, 2445-2449.

Say, T. (1817) An account of the Crustacea of the United States. Journal of the Academy of Natural Sciences of Philadelphia, 1, 57-63.

Tepolt, C.K., Bagley, M.J., Geller, J.B. \& Blum, M.J. (2006) Characterization of microsatellite loci in the European green crab (Carcinus maenas). Molecular Ecology Notes, 6, 343-345.

Tepolt, C.K., Darling, J.A., Bagley, M.J., Geller, J.B., Blum, M.J. \& Grosholz, E.D. (2009) European green crabs (Carcinus maenas) in the northeastern Pacific: genetic evidence for high population connectivity and current-mediated expansion from a single introduced source population. Diversity and Distributions, 15, 997-1009.

Transport Canada (2007) A guide to Canada's ballast water control and management regulations, 7th edn. TP13617E, 48 pp.

Wilson, J.R.U., Dormontt, E.E., Prentis, P.J., Lowe, A.J. \& Richardson, D.M. (2009) Something in the way you move: dispersal pathways affect invasion success. Trends in Ecology and Evolution, 24, 136-144.

Wirtz, P. (1999) Mother species-father species: unidirectional hybridization in animals with female choice. Animal Behaviour, 58, 1-12.

Wonham, M. \& Carlton, J. (2005) Cool-temperate marine invasions at local and regional scales: The Northeast Pacific Ocean as a model system. Biological Invasions, 7, 369-392.

\section{SUPPORTING INFORMATION}

Additional Supporting Information may be found in the online version of this article:

Figure S1 Major points of origin for ballast from Canadian Maritime sources discharged into Placentia Bay.

Table S1 Haplotype identities and frequencies for north-west Atlantic and Newfoundland populations.

Table S2 Pairwise $\Phi_{\text {ST }}$ matrix of European, north-west Atlantic and Newfoundland populations.

As a service to our authors and readers, this journal provides supporting information supplied by the authors. Such materials are peer-reviewed and may be re-organized for online delivery, but are not copy-edited or typeset. Technical support issues arising from supporting information (other than missing files) should be addressed to the authors.

\section{BIOSKETCH}

A. M. H. Blakeslee is a postdoc in the Marine Invasions Laboratory at the Smithsonian Environmental Research Center and is interested in biogeographic, phylogeographic and demographic patterns of global marine invaders.

Author contributions: All authors jointly conceived the ideas; A.M.H.B., C.H.M., J.A.D. and J.R. collected the data; A.M.H.B., C.H.M., J.A.D. and J.R. analysed the data; and A.M.H.B., C.H.M. and J.A.D. led the writing.

Editor: Mark A. Burgman 